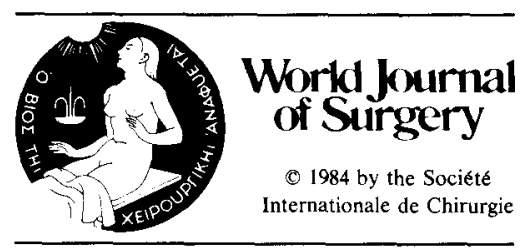

\title{
MEN I Pancreas: A Histological and Immunohistochemical Study
}

\author{
Norman W. Thompson, M.D., Ricardo V. Lloyd, M.D., Ronald H. Nishiyama, M.D., Aaron I. Vinik, \\ M.D., William E. Strodel, M.D., Maria D. Allo, M.D., Frederic E. Eckhauser, M.D., Gary Talpos, \\ M.D., and Tim Mervak, M.D.
}

Department of Surgery, Division of Endocrine Surgery, and Department of Pathology, The University of Michigan, Ann Arbor, Michigan, U.S.A.

The spectrum and extent of islet cell histopathological findings in patients with multiple endocrine neoplasia, type I (MEN I) syndrome has never been clearly defined. Although some patients have discreet tumors causing clinically evident syndromes, others may have no symptoms until metastatic islet cell carcinoma is apparent. Whether diffuse islet cell disease occurs in all patients with grossly apparent tumors is not known. This study is an attempt to define both the functional and anatomical extent of islet cell disease and its relationship with the clinical course of patients with MEN I syndrome.

The resected specimens of pancreas from 14 patients with MEN I syndrome were evaluated for hyperplasia, nesidioblastosis, multiple tumors, and evidence of malignancy. In 12 cases, specimens consisted of distal pancreas and, in 2 cases, the entire pancreas was available. Multiple sections were taken from each specimen. Immunoperoxidase staining was done for gastrin, pancreatic polypeptide, glucagon, serotonin, VIP, somatostatin, and neuron-specific enolase in sections of 24 tumors from 10 patients. Five of the 10 patients with Zollinger-Ellison syndrome underwent total gastrectomy and 3 others underwent only pancreatic procedures to control their acid hypersecretion.

The following is concluded. All MEN I patients with pancreatic neoplasms have diffuse islet cell involvement consisting of nesidioblastosis, micro- and macronodular hyperplasia. Some tumors produce multiple hormones and these patients are at risk to develop new tumors, but complete excision of grossly apparent tumors may result in

Presented at the International Association of Endocrine Surgeons at Hamburg, September 1983.

Reprint requests: Norman W. Thompson, M.D., Chief, Division of Endocrine Surgery, The University of Michigan Hospitals, D2227 South Ambulatory Care Building, Ann Arbor, Michigan 48109, U.S.A. long-term control of the endocrinopathy present. This is particularly true for patients with insulinoma and hypoglycemia. Selected patients with gastrinoma may also be considered for excision of their islet cell tumor(s) without concomitant gastrectomy, especially if transhepatic venous sampling demonstrates a single site of excess gastrin production. However, if transhepatic venous sampling demonstrates diffuse sources of hypergastrinemia, a local pancreatic procedure will invariably be unsuccessful. Total pancreatectomy in MEN I patients with disease localized to the pancreas is the only curative surgical procedure but is rarely indicated.

The extent of islet cell histopathological findings in patients with multiple endocrine neoplasia, type I (MEN I) syndrome has never been clearly defined. Although some patients with clinically detectable tumors present with recognizable symptoms, others may have no symptoms until metastatic islet cell carcinoma is apparent. Some patients with clinical findings such as Zollinger-Ellison syndrome (ZES) have no demonstrable gross pancreatic findings [1-5]. Whether diffuse islet cell disease is present in all patients with grossly apparent tumors is not known. Furthermore, it is not known how frequently new tumors develop in patients with MEN I syndrome after local excision or partial pancreatectomy for primary islet cell tumors. The present study was done to better define the functional and anatomical extent of islet cell disease in MEN I patients and to correlate it with the postoperative clinical course. Based on this study we hope to develop a more rational therapeutic plan for the pancreatic component in patients with MEN I syndrome. 
Table 1. MEN I syndrome-clinical features.

\begin{tabular}{|c|c|c|c|c|c|c|c|c|}
\hline $\begin{array}{l}\mathrm{Pa}- \\
\text { tient }\end{array}$ & Age & Year & $\begin{array}{l}\text { Syn- } \\
\text { drome }\end{array}$ & Gross finding & $\begin{array}{l}\text { Lymph } \\
\text { nodes }\end{array}$ & Operation $^{a}$ & Results & Follow-up \\
\hline 1 & $47 f$ & 1964 & $\mathrm{ZE}$ & Multiple tumors & $1+$ & TG, DP & $\uparrow$ gastrin & 21 years \\
\hline 2 & $52 f$ & 1970 & $\mathrm{ZE}$ & $1-\mathrm{cm}$ tumor, head & - & Autopsy & - & - \\
\hline 3 & $41 f$ & 1973 & $\begin{array}{l}\text { Hypogly- } \\
\text { cemic }\end{array}$ & 1.5-cm tumor, head & $1+$ & ET, DP & Euglycemic & 10 years \\
\hline 4 & $43 f$ & 1975 & $Z E$ & 1-cm tumors (2), body & - & TG, DP & $\uparrow$ gastrin & 8 years \\
\hline 5 & $27 f$ & 1975 & $\mathrm{ZE}$ & No tumors & - & TG, DP & PO death, infection & \\
\hline 6 & $52 \mathrm{~m}$ & 1978 & $\begin{array}{l}\text { Hypogly- } \\
\text { cemic }\end{array}$ & 1-cm tumor, body & - & DP & Euglycemic & 5 years \\
\hline 7 & $43 f$ & 1978 & $\mathrm{ZE}$ & 11-cm tumor, body & - & TG, DP & $\uparrow$ gastrin & 5 years \\
\hline 8 & $39 \mathrm{~m}$ & 1979 & $\mathrm{ZE}$ & $\begin{array}{l}2 \text { tumors, head, duo- } \\
\text { denum }\end{array}$ & - & ET(s), DP & Gastrin $<150$ & 4 years \\
\hline 9 & $47 \mathrm{f}$ & 1980 & $\uparrow \mathrm{PP}$ & $\begin{array}{l}\text { Invading tumor, head, } \\
\text { multiple adenomas }\end{array}$ & + & Total pancr. & Death, metastatic $\mathrm{Ca}$ & 6 months \\
\hline 10 & $52 \mathrm{f}$ & 1980 & $\mathrm{ZE}$ & $\begin{array}{l}3 \text { tumors, head, duo- } \\
\text { denum }\end{array}$ & - & ETS(s) V\&P & Sl $\uparrow$ gastrin & 3 years \\
\hline 11 & $28 \mathrm{~m}$ & 1981 & None & 2 tumors, body & - & DP & Doing well & 2 years \\
\hline 12 & $29 \mathrm{f}$ & 1982 & $\mathrm{ZE}$ & 2-cm tumor, body & - & $\mathrm{DP}$ & Gastrin $<150$ & 1 year \\
\hline 13 & $51 \mathrm{~m}$ & 1982 & $\mathrm{ZE}$ & $2.5-\mathrm{cm}$ tumor, head & $1+$ & $\mathrm{ET}, \mathrm{DP}$ & Gastrin $<150$ & 1 year \\
\hline 14 & $29 f$ & 1983 & $\mathrm{ZE}$ & 3 tumors, head, body & $1+$ & $\mathrm{ET}, \mathrm{DP}, \mathrm{TG}$ & Doing well & $<1$ year \\
\hline
\end{tabular}

aTotal gastrectomy (TG), 70\% distal pancreatectomy (DP), enucleation of tumor (ET).

\section{Methods and Materials}

\section{Patients}

The case records of $14 \mathrm{MEN}$ I patients who underwent partial or total pancreatectomy for islet neoplasms were reviewed carefully for clinical symptoms as well as for laboratory and operative findings. In 12 patients who survived, postoperative symptoms, laboratory, and other diagnostic studies were also reviewed. In addition, each of the patients was re-examined, and serum was obtained for determination of gastrointestinal polypeptide hormone levels. Other studies, including abdominal computed tomography scans, were obtained when indicated. Follow-up in 12 living patients has been complete to date (Table 1).

\section{Pathological Methods}

The resected specimens of pancreas from the $14 \mathrm{pa}-$ tients with proven MEN I syndromes were evaluated for gross and microscopic tumors, evidence of malignancy, islet cell hyperplasia, and nesidioblastosis. Lymph nodes removed at the time of operation, or at autopsy (in 1 case), were also evaluated. All but 2 specimens consisted of distal pancreas. Any islet cell tumors that had been enucleated from the pancreatic head, uncinate process, or duode- num were also evaluated in each case. The latter specimens were all obtained surgically at the time of exploration in patients with either Zollinger-Ellison syndrome or organic hyperinsulinism. In 1 case, 2 incidental pancreatic tumors were resected during an operation for cholelithiasis. In another case, the entire pancreas was available for evaluation following total pancreatectomy for an adenocarcinoma arising in the head of the pancreas. The pancreas was removed at autopsy in 1 patient, after the patient had died from hypercalcemic crisis before any surgical intervention. In each case, multiple sections of tumors and nontumorous pancreas were stained with hematoxylin and eosin and reviewed using light microscopy.

\section{Immunohistochemical Localization}

In 10 cases, immunohistochemical staining for detection of polypeptide hormones, serotonin, and neuron-specific enolase (NSE) was done in 1 or more tumors. The method consisted of cutting 4- $\mu$ sections of formalin-fixed, paraffin-embedded tissues and immuno-peroxidase staining them using the avidin-biotin complex method $(\mathrm{ABC})$ with an unlabeled primary antibody and biotinylated secondary antibody in a performed avidin:biotin horseradish peroxidase complex (Vector Labs, Burlingame, CA) [6]. Tissues were treated with di- 
aminobenzidine and counterstained with hematoxylin. Sources of antisera and dilutions used included insulin $(1: 1,000)$ (Dr. Besch, Indiana University), glucagon (1:10) (Calbiochem, CA), human pancreatic polypeptide $(1: 2,000)$ (Dr. R. Chance, Eli Lilly), somatostatin $(1: 100)$ (Immunonuclear, MN), VIP (1:2) (Immulak, CA), ACTH $(1: 1,000)$ (Dako, CA), calcitonin (1:200) (Immunonuclear, $\mathrm{MN}$ ), serotonin $(1: 200)$ (Immunonuclear, $\mathrm{MN}$ ), gastrin (1:10) (Calbiochem, CA), and NSE (1:500) (Dr. P. Marango, NIMH, MD). Antisera for glucagon, gastrin, and VIP were previously diluted by distributors. Serial sections of each tumor were incubated with the various antisera. Normal pancreas was used as a control for insulin, glucagon, somatostatin, and pancreatic polypeptide immunohistochemistry. Sections of gastric antrum were used for gastrin. Primary antisera were omitted for negative controls. In addition, the specificity of each antiserum was examined by specific absorption with appropriate antigens. The concentrations of antigens used to absorb the antisera ranged from 10 to $100 \mathrm{ng} / \mathrm{ml}$ in purified form.

\section{Results}

\section{Patients}

There were 10 female and 4 male MEN I patients in this study group (Table 1). Only 2 patients (nos. 4 and 9) were members of the same kindred. The mean age of all patients at the time of diagnosis of pancreatic islet cell disease was 42.5 years. The mean age was 41.4 years (range 27-52) for females and 45.5 years (range 28-52) for males. Eight of 10 patients had ZES confirmed by demonstrating gastric hyperacidity (BAO-MAO ratio greater than 0.6), elevated basal serum gastrin levels, or a paradoxical rise in serum gastrin levels after stimulation with intravenous secretin. One patient (no. 2) died from hypercalcemic crisis and massive hemorrhage from a duodenal ulcer within an hour of hospitalization. Autopsy demonstrated massively enlarged parathyroid glands, a pituitary microadenoma, an islet cell adenoma, and a large duodenal ulcer [7]. One patient (no. 1) underwent total gastrectomy before serum gastrin assays were available but has since demonstrated elevated serum gastrin levels. Since 1979, a total of 7 patients (nos. 8-14) have had selective portal venous sampling for gastrin and other gastrointestinal polypeptide hormones prior to a planned pancreatic operation $[8$, 9]. Two patients presented with episodic hypoglycemia (nos. 3 and 6) and were found at opera- tion to have insulinomas. Both had preoperative insulin/glucose ratios greater than 0.3 . Neither has had recurrent symptoms or laboratory evidence of hypoglycemia since undergoing distal pancreatectomy. One patient (no. 9) who had undergone subtotal parathyroidectomy had no gastrointestinal symptoms during a 5-year period until he suddenly developed obstruction of the second portion of the duodenum. During this asymptomatic interval, his serum pancreatic polypeptide level was consistently elevated. Repeated serum gastrin levels were normal until he developed duodenal obstruction. This patient was found at operation to have an adenocarcinoma of the pancreatic head invading the duodenum [9]. In addition, he had multiple islet cell adenomas, extensive nesidioblastosis, and islet cell hyperplasia involving the entire pancreas. After an uncomplicated recovery following a total pancreatectomy, he developed metastases 6 months later and died shortly afterward. One patient (no. 11) without any symptoms related to the pancreas had 2 islet cell adenomas in the body of the pancreas at the time of a cholecystectomy. The adenomas, which measured 4 and $2.5 \mathrm{~cm}$, respectively, were resected with the body and tail of the pancreas. This patient had undergone a subtotal parathyroidectomy for chief cell hyperplasia 5 years previously at age 23 years.

Eleven patients had undergone previous parathyroidectomy before any manifestations of islet cell disease developed (mean interval 3.9 years). The remaining 3 patients were hypercalcemic at the time their pancreatic disease was discovered. The duration of antecedent hyperparathyroidism cannot be documented clearly but 2 of these patients had renal calculi for at least 3 years. Of these 3 patients, 2 had parathyroidectomy before their pancreatic operation. The remaining patient died from hypercalcemic crisis before any operation could be undertaken. Thus, each of the 13 patients undergoing a pancreatic operation had a previous parathyroidectomy. All had chief cell hyperplasia of all 4 parathyroid glands. In each case, all but the equivalent of 1 normal parathyroid gland (30-50 $\mathrm{mg}$ ) was resected. All patients are currently normocalcemic.

Nine of the 14 patients had pituitary tumors documented by CT scanning, abnormal pituitary hormone levels, hypophysectomy, or autopsy. Two patients (nos. 5 and 10) underwent hypophysectomy before either parathyroid or islet cell disease was treated. Another patient (no. 14) was treated with bromocryptine for 2 years before symptoms of ZES developed.

Three patients had evidence of adrenocortical disease. Of these, 2 (nos. 2 and 7) had clinical manifestations of Cushing's syndrome. 
Table 2. Pancreatic pathological findings in 14 MEN I patients (light microscopy).

\begin{tabular}{|c|c|c|c|c|c|}
\hline Patient & Nesidioblastosis & Hyperplasia & Microadenomas & Gross tumor(s) & Metastatic lymph nodes \\
\hline 1 & + & + & t & $+(\mathrm{s})$ & + \\
\hline 2 & + & + & + & + & - \\
\hline 3 & + & + & + & + & + \\
\hline 4 & - & + & + & $+(s)$ & - \\
\hline 5 & + & + & + & - & - \\
\hline 6 & + & + & + & $+(s)$ & - \\
\hline 7 & + & + & + & $+11 \mathrm{~cm}$ & - \\
\hline 8 & + & + & + & $+(\mathrm{s})$ & - \\
\hline 9 & + & + & t & $+(s)$ & + \\
\hline 10 & + & t & + & $+(s)$ & - \\
\hline 11 & + & + & + & $+(s)$ & - \\
\hline 12 & + & + & + & $+(s)$ & - \\
\hline 13 & + & + & t & $+2.5 \mathrm{~cm}$ & - \\
\hline 14 & + & + & + & $+(\mathrm{s})$ & + \\
\hline Total & 13 & 14 & 14 & $13(9)$ & 4 \\
\hline
\end{tabular}
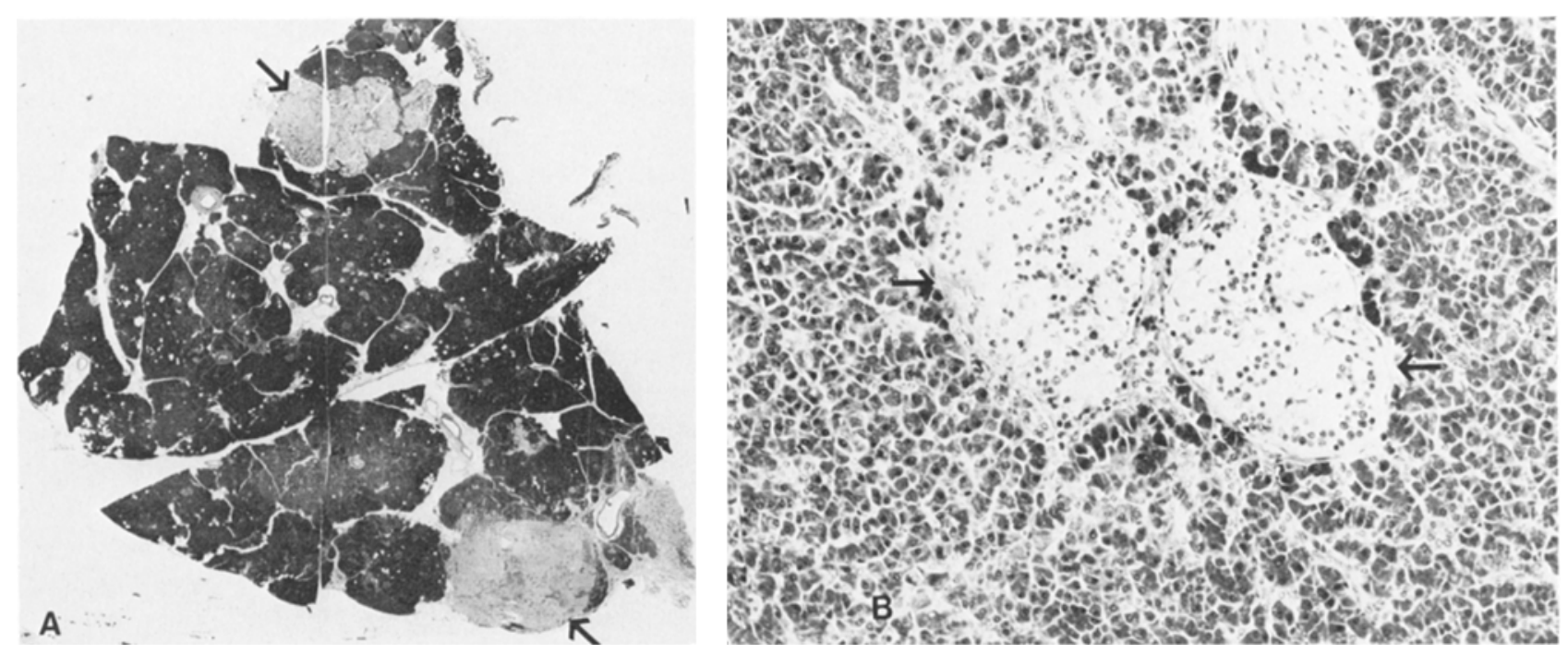

Fig. 1A. Patient no. 13, a 51-year-old male with ZES. A $2.5-\mathrm{cm}$ gastrinoma was enucleated from the pancreatic head and a distal pancreatectomy was performed. This section from the tail shows multiple adenomas (arrows). H\&E $\times 25$. B. Section through body of pancreas from same patients showing islet cell hyperplasia with amyloid-like material. $\mathrm{H} \& \mathrm{E} \times 160$.

Of the 10 ZES patients, 5 had total gastrectomies in addition to pancreatic resections. Only 1 of the 5 MEN I patients operated on since 1979 has had a gastric resection. All have undergone distal panatectomy with or without enucleation of tumor(s) in the head of the pancreas or duodenum. One patient had excision of 3 small tumors from the duodenum and pancreatic head and a concomitant vagotomy and pyloroplasty. Currently, these patients are all doing well and none requires antacids or cimetidine. However, their serum gastrin levels are now either borderline normal or slightly elevated. All now demonstrate a positive gastrin response to intravenous secretin stimulation. Three patients (nos. 1, 3, and 7) who underwent total gastrectomy currently have elevated serum gastrin lev- els but no clinically detectable metastatic disease. They remain symptom free at 21 years, 8 years, and 5 years, respectively, after operation. One of these patients was explored 5 years following total gastrectomy for an unrelated reason and was found to have a firm pancreatic head but no palpable tumor or evidence of metastatic disease. Serum gastrin levels have remained near $1,000 \mathrm{pg} / 100 \mathrm{ml}$ for 5 years in this patient.

\section{Pathological Findings}

Microscopic examination of the non-tumorous segments of pancreas showed diffuse islet cell 


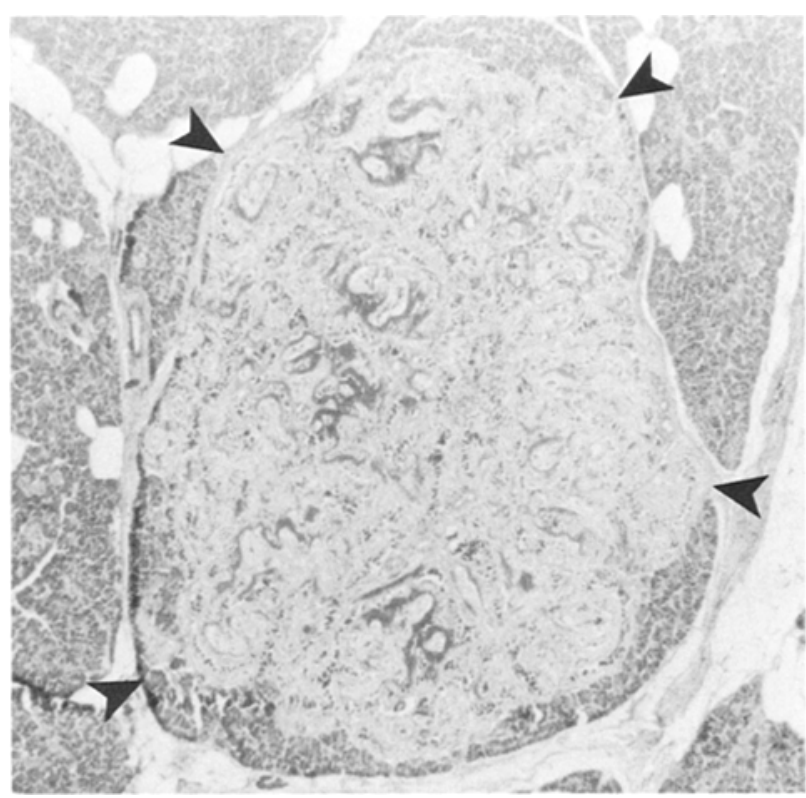

Fig. 2. Patient no. 8, a 39-year-old male with ZES. Section through tail of pancreas showing 1 of many microadenomas. $\mathrm{H} \& \mathrm{E} \times 160$.

hyperplasia and microadenomas in all 14 patients (Table 2, Fig. 1). Nesidioblastosis (islet cells arising from exocrine ducts) was demonstrated in all but 1 patient (no. 4). Grossly visible tumors were present in 13 of 14 patients and were multiple in 7. Two patients had duodenal islet cell tumors in addition to pancreatic neoplasms (Fig. 2). Most of the tumors were $2 \mathrm{~cm}$ or smaller in maximum diameter. The largest tumor was an 11-cm "adenoma" involving the body and tail of the pancreas in a patient with ZES (Fig. 3). In 4 patients, single, enlarged peripancreatic lymph nodes were found to contain microscopic metastases. One patient (no. 9) with metastatic adenocarcinoma in a peripancreatic lymph node and a primary adenocarcinoma of pancreatic duct origin, arising in the head of the pancreas, also had multiple islet cell tumors. No patient with islet cell tumors was proven to have hepatic metastases at operation or subsequent follow-up.

\section{Immunohistochemical Findings}

The results of immunohistochemical localization studies for selected polypeptide hormones, serotonin, and NSE are shown in Table 3. Twenty-four

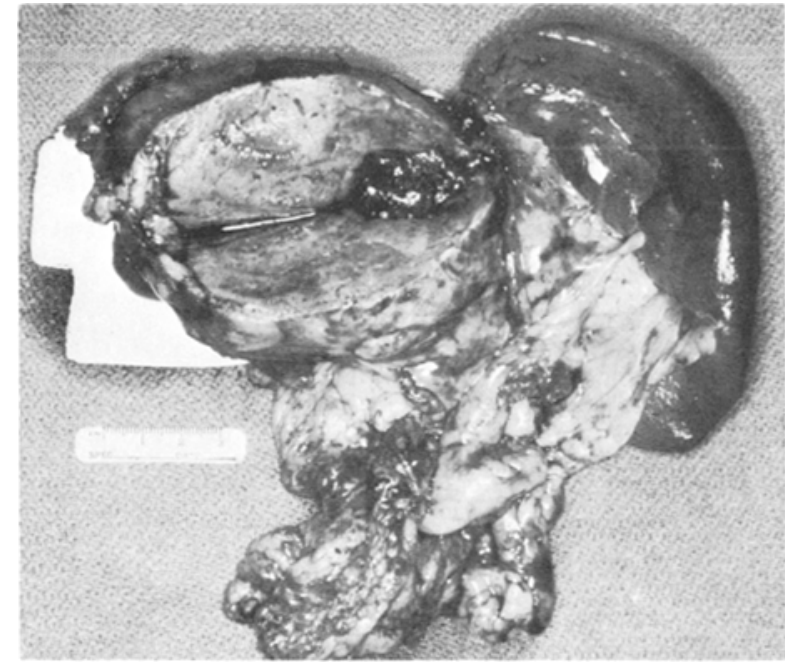

Fig. 3. Patient no. 7. Surgical specimen, distal pancreatectomy and splenectomy in 43-year-old female with $\mathrm{ZES}$ and an $11-\mathrm{cm}$ gastrinoma.

tumors from 10 patients were studied. In all but 1 patient (no. 2), more than 1 tumor was found. In the most recent patient (no. 14), a metastatic lymph node was stained in addition to 3 tumors. In this patient with ZES, the metastatic lesion was positive for somatostatin only; this peptide was also demonstrated in 1 of the 3 pancreatic tumors. Of 8 patients with ZES, 6 were found to have gastrin in at least 1 of the tumors studied. The 1 patient with hypoglycemia was found to have insulin in 1 of 3 neoplasms, whereas the other tumors had both glucagon- and gastrin-positive cells. Eight of 10 patients had PP within their tumors and 18 of 24 neoplasms had PP-containing cells. Every tumor stained positively for neuron-specific enolase. Heterogeneity of endocrine cells within individual neoplasms was demonstrated in $17(71 \%)$ of 24 tumors.

\section{Discussion}

This study suggests that the pancreas is uniformly involved in patients with MEN I syndrome. Where complete pathological data have been reported, the pituitary, parathyroids, and pancreas have been involved [10]. However, the extent and nature of the pancreatic involvement, other than for gross tumors, have frequently been omitted. This study clarifies the extent of islet cell disease and relates 
Table 3. Immunohistochemical localization of polypeptide hormones, serotonin, and NSE in pancreatic tumors of MEN I patients. ${ }^{a}$

\begin{tabular}{|c|c|c|c|c|c|c|c|c|c|c|}
\hline Patient & Syndrome & Tumor(s $)^{b}$ & $\mathrm{PP}$ & INS & Serot & GLU & SRIF & VIP & Gastrin & NSE \\
\hline 2 & ZES & I & - & - & $t^{f}$ & - & $t^{\mathrm{f}}$ & + & $+^{\mathrm{f}}$ & + \\
\hline \multirow[t]{3}{*}{4} & ZES & I & + & - & - & $+\mathrm{f}$ & $+{ }^{\mathrm{f}}$ & - & - & + \\
\hline & & II & + & $+{ }^{\mathrm{f}}$ & - & - & $+{ }^{\mathrm{f}}$ & - & $t^{f}$ & + \\
\hline & & III & + & + & - & $t^{\mathrm{f}}$ & $+^{\mathrm{f}}$ & - & - & + \\
\hline \multirow[t]{2}{*}{5} & ZES & I & + & - & - & + & $+\mathrm{f}$ & - & - & + \\
\hline & & II & + & $t^{f}$ & - & + & $+^{\mathrm{f}}$ & - & - & + \\
\hline \multirow[t]{3}{*}{6} & Insulinoma & I & + & - & $t^{\mathrm{f}}$ & + & $+{ }^{\mathrm{f}}$ & - & $t^{\mathrm{f}}$ & + \\
\hline & & II & + & + & $+^{\mathrm{f}}$ & - & $+^{\mathrm{f}}$ & - & $t^{f}$ & + \\
\hline & & III & + & - & $t^{f}$ & - & - & - & - & t \\
\hline \multirow[t]{2}{*}{7} & ZES & I & + & - & - & - & - & $+^{\mathrm{f}}$ & $+^{\mathrm{f}}$ & t \\
\hline & & II & - & - & - & - & - & - & - & + \\
\hline \multirow[t]{2}{*}{8} & ZES & I & + & - & - & - & $t^{\mathrm{f}}$ & - & + & + \\
\hline & & II & + & + & - & - & $t^{\mathrm{f}}$ & - & - & + \\
\hline \multirow[t]{2}{*}{9} & PP & I & + & $t^{f}$ & - & + & $+^{\mathrm{f}}$ & - & - & + \\
\hline & & II & + & $+^{\mathrm{f}}$ & - & + & $t^{\mathrm{f}}$ & - & - & + \\
\hline \multirow[t]{2}{*}{12} & ZES & I & + & - & - & - & - & - & + & + \\
\hline & & II & + & - & - & - & - & - & - & + \\
\hline \multirow[t]{3}{*}{13} & ZES & I & - & - & - & - & - & - & + & + \\
\hline & & II & - & + & - & - & - & - & - & + \\
\hline & & III & - & - & - & + & - & - & - & + \\
\hline \multirow[t]{4}{*}{14} & ZES & I & $+{ }^{\mathrm{f}}$ & - & & - & - & - & - & + \\
\hline & & II & $+^{\mathrm{f}}$ & + & & - & $t^{\mathbf{f}}$ & - & - & + \\
\hline & & III & $+^{f}$ & + & & - & - & - & - & + \\
\hline & & IV & - & - & & - & $+^{\mathrm{f}}$ & - & - & + \\
\hline
\end{tabular}

${ }^{a} \mathrm{PP}=$ pancreatic polypeptide; INS $=$ insulin; Serot $=$ serotonin $; \mathrm{GLU}=$ glucagon; SRIF $=$ somatostatin; VIP $=$ vasoactive inhibitory peptide; NSE = neuron-specific enolase.

${ }^{b} \mathrm{I}, \mathrm{II}, \mathrm{III}$ are different tumors; IV is metastatic lymph node

$+^{f}=$ focal stainins of tumor cells.

it to the functional aspects of the disease process. In each of the cases studied, diffuse islet cell disease was found. With the exception of 1 patient, hyperplasia and nesidioblastosis were demonstrated in all specimens from patients in whom neoplasms had been excised at operation or at autopsy. In the patient without nesidioblastosis, multiple sections showed hyperplasia and microadenomatosis. All patients had microadenomas occurring throughout the non-tumor-containing areas of pancreas.

Some tumors produced multiple hormones and were composed of heterogeneous islet cells. Most patients had tumors that stained for one or more gut or pancreatic hormones. These findings are consistent with the observation that metachronous hormonal syndromes have been reported in MEN I patients with the ZES and hypoglycemic syndromes; synchronous syndromes (ZES and glucagonoma) occur less frequently $[11,12]$. In our experience the two most common "silent" hormones found in islet cell neoplasms and microadenomas were pancreatic polypeptide (PP) and somato- statin. The presence of PP in many microadenomas corresponds in frequency to elevated serum levels of this hormone found in patients with MEN I syndrome [3-5]. We believe that if somatostatin samplings were routinely obtained in MEN I patients, levels of this hormone might also be elevated frequently. Although tumors producing either hormone alone are infrequent in the reported experience with MEN I patients, this may represent lack of recognition rather than lack of occurrence $[8,13]$. In most cases these tumors may be histochemically active but clinically silent. All of the islet cells, including stem cells arising from exocrine ducts, stained intensely with neuron-specific enolase. This study supports the observation that this enzyme is a universally present marker in neuroendocrine cells [6].

The incidence of proven malignancy in this group of patients was $29 \%$ and only 1 patient developed documented hepatic metastases. This low incidence of metastatic disease is surprising, particularly for the group of patients with ZES (20\%), since it has been shown previously that $60 \%$ or 
more of such patients have malignant tumors as determined by metastases at the time of diagnosis [1, 4, 14-16]. Two of the ZES patients are noteworthy; the longest survivor at 21 years was found to have 1 positive lymph node at the time she underwent distal pancreatectomy and total gastrectomy. A 43-year-old female patient with a short history of diarrhea due to gastric hypersecretion had an $11-\mathrm{cm}$ tumor but no metastases or local invasion. Like the other ZES patients, she continues to have a positive secretin response (rise in serum gastrin of $200 \mathrm{pg} / \mathrm{ml}$ from basal levels). None of these patients has developed liver metastases.

The occurrence of adenocarcinoma arising in the MEN I pancreas is rare but may not be mere coincidence. Patient no. 9 had been followed for 5 years after a subtotal parathyroidectomy. Throughout that time, fasting serum levels of pancreatic polypeptide were markedly elevated. To rule out the possibility of a pancreatic tumor, he underwent selective pancreatic arteriography. The study was considered normal. At the time of total pancreatectomy 4 years later, the entire pancreas was grossly thickened and slightly nodular. The islet cell histopathological finding was the most extreme seen in any patient. The combination of nesidioblastosis, islet cell hyperplasia, and micro- as well as macroadenomatosis, had nearly replaced the normal acinar pancreas. The adenocarcinoma, arising in the head of the pancreas, was surrounded by a rim of islet cells that stained positively for gastrin. Serum gastrin levels were first elevated just prior to operation at which time selective portal venous sampling showed a slight but definitely positive gradient for gastrin in the head of the pancreas. This adenocarcinoma may be an example of a "reversed nesidioblastosis," a regression or de-differentiation from islet cell to adenocarcinoma. At least one other similar case has been reported [9].

Since all of the patients diagnosed since 1975 were known to have MEN I syndrome because of family history, asymmetrical parathyroid hyperplasia, or pituitary adenomas, the islet cell disease may have been detected at an earlier stage than in many previous reports. This may have resulted in a lower than expected rate of malignancy. Several patients were screened annually for pancreatic endocrine disease. In 2 MEN I patients with hypergastrinemia and peptic ulcer disease, serum gastrin levels returned to normal after correction of the hypercalcemia. In patient no. 4, hypergastrinemia developed 3 years after a successful parathyroidectomy. The first manifestation of ulcer disease was an acute perforation of the duodenum. At operation, 2 small tumors were palpable within the body of the pancreas. The patient was treated with distal pancreatectomy and total gastrectomy. Al- though asymptomatic, she was thought to have hepatic metastases because of a suspicious liver scan and progressively rising serum gastrin levels to over $1,000 \mathrm{pg} / \mathrm{ml}$ during a 5 -year period. Selective pancreatic venous sampling showed that the only positive gastrin gradient occurred in the region of the head of the pancreas. When explored during a hysterectomy in 1981, no tumor was palpable in the liver, lymph nodes, or the thickened pancreatic head.

It is not known whether MEN I patients with malignant gastrinomas or other islet cell tumors really have a better prognosis than those with sporadic islet cell malignancies. In one of the few studies to evaluate sporadic gastrinomas separately from those occurring in patients with the MEN I syndrome, it was found that only $1(7 \%)$ of 14 patients with MEN I gastrinoma had died as a result of disease progression during a follow-up period of 5 years or longer [17]. Because these patients continued to manifest hypergastrinemia after pancreatic operations despite a stable clinical course, it was concluded that MEN I patients with ZES should not undergo abdominal operation. However, Friesen reported long-term results in 23 ZES patients and found that 8 tumor deaths had occurred, 4 in patients with MEN I syndrome [4]. Two MEN I patients with liver metastases survived for 9 and 11 years, respectively, after total gastrectomy. Most authors fail to distinguish between sporadic and MEN I gastrinomas or only mention the incidence of each without any further details $[1,2,14,16,18]$. It is clear, however, that some MEN I patients with ZES do eventually die from their neoplasms. The presence or potential for malignancy cannot be ignored if these patients are to have optimal management of their disease.

Despite the apparent futility of eliminating hypergastrinemia in MEN I patients by anything less than a total pancreatectomy, it appears that most patients with hypoglycemia can be effectively treated if all primary macroscopic tumors and metastases are removed. In this series, 2 MEN I patients with organic hypoglycemia had excellent results following distal pancreatectomy. Follow-up in these patients ranged from 5 to 10 years. In the patient followed for 10 years, a single lymph node metastasis confirmed that the primary neoplasm was malignant. Both of these patients were operated on before selective venous insulin sampling was available. In each case, all palpable tumor was removed with the resected specimen. Recently, we have had the opportunity to study an MEN I patient who was referred because of persistent hypoglycemia following enucleation of an insulinoma in the tail of the pancreas [19]. By using selective venous sampling, a second tumor was localized to the 
body of the pancreas. This lesion was subsequently removed by distal pancreatectomy. It is of interest that immuno-peroxidase staining of tumors from 5 patients without hypoglycemic symptoms were positive for insulin. Four of these tumors were shown to produce other hormones as well. Whether or not resection of these tumors has prevented the development of hypoglycemia in some of these patients is unknown. Demonstration of insulin production by these tumors may not necessarily correlate with biological activity. In these patients, all of whom have diffuse islet cell dysplasias, tumors secreting other hormones may also be present or develop later in the course of the disease. Preoperative localization of the source of excess insulin secretion in the MEN I patient is, therefore, of great therapeutic importance [19]. In contrast to ZES patients, of whom $30-40 \%$ are classified as MEN I, only 3-4\% of patients with "insulinomas" are afflicted with this disorder [7].

The pathological findings of the MEN I pancreas have not been clearly defined except in isolated case reports. In the present study, islet cell neoplasms $1 \mathrm{~cm}$ or larger were identified in all but $1 \mathrm{pa}-$ tient with ZES. The majority of patients (9 of 14) had more than 1 tumor and all patients had diffuse hyperplasia and microadenomas throughout the non-tumorous pancreas. Nesidioblastosis was also present in nearly all sections reviewed. This histopathologic study suggests that MEN I patients have diffuse dysplasia of islet tissue from which adenomas and islet cell carcinoma may develop. The factors that promote the development and growth of these tumors are unknown. In this series, the mean age at the time of tumor diagnosis was 43 years. However, 3 of the most recent patients were diagnosed before the age of 30 . Two of these patients had hypergastrinemia with minimal symptoms but were studied because of parathyroid hyperplasia or a positive family history. It is likely that in the past such patients may well have been followed for many years before their islet cell disease was recognized. We have not seen peptic ulcers or other manifestations of MEN I islet cell disease in any patient under the age of 25 years. When children have ZES, they usually have sporadic, single gastrinomas rather than MEN I syndrome [18]. MEN I patients appear to be at life-long risk for the development of pancreatic disease. This point was recently emphasized in a report of an MEN I octogenarian who presented with functional islet cell tumors [20].

The present study supports the contention that MEN I patients may have tumors with the potential to secrete multiple hormones. Based on immunohistochemical studies, our review has shown that all patients have tumor(s) with the potential to se- crete more than 1 hormone. The lack of PP in the tumors of 2 ZES patients does not necessarily imply that other adenomas or hyperplastic islet cells secreting this peptide were absent. However, it is noteworthy that in 1 of these patients (no. 13), preoperative selective venous assays for $\mathrm{PP}$ were within the normal range. This contrasts with the high levels seen in most other MEN I patients undergoing similar studies. In our series, gastrin was identified in at least 1 tumor in 6 of the 8 patients with ZES and in 1 patient with hypoglycemia who had no evidence of ulcer disease or diarrhea. This finding is in accord with reports of others who studied gastrinomas by the immunoperoxidase method [21-25]. In a study by Solcia et al. [24], gastrin was found by immuno-peroxidase techniques or by extraction in 25 of 36 pancreatic tumors from ZES patients. Creutzfeldt et al. [21] reported similar findings in 20 of 21 ZES tumors as did Woodtli and Hedinger [25] in 7 of 9 patients. Failure to identify gastrin is most likely explained by inappropriate fixation and processing of tumor tissue or sampling deficiencies when multiple tumors are present [23]. Another possibility is that rapid turnover can result in tumor cell depletion, reducing the amounts of stored gastrin to levels too small for immunocytochemical detection [24]. A further explanation is that gastrin might be secreted by newly formed islet cells arising from ductal epithelium. This explanation appears unlikely in view of endocrine cell studies in patients with pancreatic or duodenal gastrinomas by Solcia et al. [24]. They were unable to demonstrate gastrin-immunoreactive cells in the non-tumorous pancreas. Cells exhibiting nesidioblastosis and hyperplastic islet cells were positive for PP, glucagon, somatostatin, or insulin. Whether functioning microadenomas can produce enough gastrin to cause hypergastrinemia in patients with ZES cannot be proven from this or other studies. In this series, 1 patient with ZES had no grossly identifiable tumor on sectioning the entire pancreas. In view of the high incidence of negative pancreatic explorations in ZES patients, it seems reasonable to speculate that microadenomas may be the source of excessive gastrin production rather than a non-pancreatic source $[2,11]$.

The pathological findings in this study suggest that patients with MEN I pancreatic disease may not be "cured" by any surgical procedure less than total pancreatectomy because of the diffuse nature of the islet cell dysplasia. On the other hand, clinical experience does not justify total pancreatectomy because of the initial operative mortality rate, the possibility of undetected hepatic metastases, long-term morbidity from insulin-dependent diabetes, and the reasonably good prognosis for the ma- 
jority of patients treated by less extensive procedures [17]. In the present series, 1 total pancreatectomy was done because of the rare synchronous occurrence of pancreatic ductal adenocarcinoma with MEN I pancreatic disease. Of 14 MEN I patients, this was the only case in which the serum gastrin level returned to normal after operation. In a recently reported series, a total pancreatectomy was done for the synchronous occurrence of hypoglycemia and ZES [11]. Both syndromes were apparently cured. In another series of patients in which a small subgroup of patients was treated by Whipple procedures, the operative mortality rate was $50 \%$ [1]. In contrast, patients in that same series, who had islet cell hyperplasia without neoplasms, did well after total gastrectomy without pancreatic resection. Eleven patients, followed for 1-15 years, were alive without evidence of metastatic disease. Another subset of patients in the series of Bonfils et al. [1] with a favorable prognosis included those with duodenal gastrinomas. In 13 patients, only 4 had lymphatic metastases. Resection of the primary tumor could be accomplished in all but 1 patient. Eleven patients followed for a period of 1-14 years did well except for one who died of tumor. In the present series, at least 2 patients had duodenal tumors in addition to pancreatic neoplasms. Whether duodenal neuroendocrine tumors are more common in MEN I patients than in sporadic cases of ZES is not currently known [26-28]. However, because duodenal neuorendocrine cell hyperplasia is common in patients with gastrinomas, this possibility merits further study. The duodenum should always be completely evaluated in MEN I patients [24].

All MEN I patients should be studied for the commonly occurring gastrointestinal-pancreatic (GEP) hormones. Virtually any GEP hormone as well as calcitonin and ACTH may be found in MEN I tumors $[29,30]$. Although it is unlikely that even when a localized source of gastrin secretion is found it will lead to permanent cure after pancreatic operations in MEN I patients with the ZES, palliation without total gastrectomy can be achieved $[8,17]$. In 4 of the present patients, enucleation of duodenal and pancreatic tumors, combined with distal pancreatectomy, has alleviated all peptic ulcer symptoms without the need for gastrectomy or cimetidine during a 1-4-year follow-up. Despite this fact, all 4 patients have elevated serum gastrin levels when stimulated with secretin. These patients may eventually require further medical or surgical therapy. In contrast, it is estimated that approximately $20 \%$ of patients with sporadic gastrinomas of either the pancreas or duodenum are amenable to local resection or enucleation with probable cure as determined by secretin testing after operation $[1,2,4,11,17,26$, 28, 31-33]. Appropriate candidates for local resection may be identified by portal venous gastrin sampling $[8,34,35]$. With earlier diagnosis of Zollinger-Ellison syndrome using gastrin radioimmunoassays, the opportunity to cure sporadic patients surgically may be further increased [36, 37].

Our current policy is to recommend selective pancreatic and hepatic venous sampling in any MEN I patient in whom an operative procedure is contemplated $[8,9,34,35]$. If there is evidence of diffuse gastrin secretion from the pancreas, it is unlikely that a primary pancreatic procedure will afford long-term relief [8]. Further studies, including $\mathrm{CT}$ and selective arteriography, should be done to identify any gross neoplasms or metastases. If none is found, a decision can be made regarding medical therapy versus total gastrectomy. As an alternative, pancreatic exploration with enucleation of any palpable tumors in the duodenum or pancreatic head, and distal pancreatectomy to remove microadenomas or to reduce potential sources of neoplasms should be considered. Whether vagotomy is of any additional benefit in these circumstances is currently debatable $[17,38,39]$. Any decision to do a total gastrectomy must be individualized. These decisions should be based on the severity of preoperative peptic ulcer disease, the ease with which acid secretion can be controlled with cimetidine, the age of the patient, and the presence or absence of metastatic disease.

If venous localization studies or $\mathrm{CT}$ scanning demonstrates a solitary pancreatic neoplasm, exploration is indicated. If the tumor is located in the pancreatic head or duodenum and if there is no local invasion, enucleation may be performed. Because of the presence of diffuse islet cell dysplasias in patients with MEN I syndromes, we recommend concomitant distal pancreatectomy to remove other small, undetectable, functional or nonfunctional islet cell neoplasms. Reducing the bulk of the pancreas may reduce the potential for developing other malignant islet cell neoplasms. A total pancreatectomy is the only procedure that may be considered curative in the MEN I patient without metastases. However, the benefits of this operation are outweighed by the operative mortality rate and long-term morbidity of insulin-dependent diabetes.

Most MEN I patients who present primarily with hypoglycemia can be cured by a single pancreatic operation $[5,9,13,15,19]$. Because of the small size and multiplicity of tumors in this syndrome, preoperative selective portal venous insulin samples should be obtained in all patients regardless of whether selective arteriography has identified one or more tumors. These patients should also be 
treated with distal pancreatectomy in addition to excision of any tumors found in the proximal pancreas. This therapy will increase the likelihood of excising other discreet yet undetectable insulinomas and will decrease the possibility of leaving non-insulin-producing neoplasms which may result in additional morbidity. In these cases, intraoperative ultrasound may be of particular value in locating small, nonpalpable tumors in the remaining pancreas [40, 41]. All available evidence suggests that hypoglycemic MEN I patients have discreet tumors as the source of their hyperinsulinism rather than either hyperplastic beta cells or nesidioblastosis that may occur as sporadic endocrinopathies in adults [19, 35, 42-45]. In the latter cases, a more extensive pancreatectomy $(80-95 \%)$ may be required to control the patient's hyperinsulinism [29].

Distal pancreatectomy with enucleation of other functional and silent tumors found in the head of the gland should be considered in managing islet cell disease in the MEN I syndrome. All of these tumors are potentially malignant, and their early detection and excision may prevent tumor-related deaths. Long-term follow-up of all MEN I patients should include periodic reassessment of gastrointestinal-pancreatic hormone levels and CT examination of the remaining pancreas.

\section{Résumé}

L'histopathologie des cellules insulaires pancréatiques des malades qui présentent un syndrome MEN I n'a jamais été parfaitement définie. Si certains parmi eux sont porteurs de petites tumeurs qui se manifestent par des syndromes cliniques patents, d'autres n'accusent aucun symptôme avant que des métastases néoplasiques ne se manifestent. En particulier, on ne sait pas si les altérations des cellules insulaires sont diffuses quand les malades présentent des tumeurs évidentes. Cette étude a pour but de définir à la fois l'importance anatomique et l'importance fonctionnelle de la maladie insulaire par rapport à son expression clinique chez les sujets concernés par ce syndrome.

Pour ce faire, des spécimens provenant de 14 malades atteints du syndrome MEN I ont été étudiés eu égard à l'hyperplasie, à la nésidioblastose, à la multiplicité des îlots tumoraux, à la malignité.

Dans 12 cas, les spécimens répondaient au pancréas distal, dans 2 cas à la totalité du pancréas. De multiples coupes furent pratiquées au niveau de chaque pièce soumise à l'examen. L'imprégnation à l'immunoperoxidase concerna les coupes de 24 tumeurs provenant de 10 patients. Cinq des 10 malades qui présentaient un syndrome de Zollinger-Ellison avaient subi une gastrectomie totale et 3 une intervention pancréatique pour contrôler leur hypersécrétion acide.

Les conclusions tirées de cette étude furent les suivantes: tous les malades accusant un syndrome MEN I et porteurs d'un néopolasme pancréatique présentaient des lésions insulaires diffuses répondant à une nésidioblastose, à une hyperplasie micronodulaire et macronodulaire. Quelques tumeurs produisaient de multiples hormones: gastrine, polypeptide pancréatique, glucagon, sérotonine, V.I.P., somatostatine, testées par la méthode. Il résulte de ces constatations que les risques de récidive tumorale après exérèse complète des tumeurs évidentes ne sont pas à écarter, encore que l'exérèse permette de contrôler longtemps l'endocrinopathie. Ceci est particulièrement vrai pour les insulinomes hypoglycémiants. En ce qui concerne les gastrinomes, leur exérèse peut être suffisante, en particulier lorsque les prélèvements veineux étagés montrent qu'ils sont uniques; la gastrectomie concomitante est alors inutile. En revanche, lorsque la gastrine est trouvée en excès au niveau de multiples échantillons veineux, l'exérèse tumorale est insuffisante et la pancréatectomie totale représente l'intervention indispensable; en fait, son indication est rare.

\section{Resumen}

La variedad del espectro de la histopatología de las células insulares en pacientes con síndrome de neoplasias endocrinas múltiples tipo I (NEM I) todavía no ha sido claramente definido. Aún cuando algunos pacientes poseen tumores discretos que causan síndromes clínicamente evidentes, otros pueden no exhibir sintomatología alguna hasta cuando se hace evidente un carcinoma metastásico de células insulares. No se sabe si hay enfermedad difusa de las células insulares en todo paciente con tumores macroscópicamente aparentes, ni además se conoce con qué frecuencia se desarrollan nuevos tumores en pacientes con síndrome NEM I después de resección local o de pancreatectomía parcial para tumores primarios de células insulares. El presente estudio intenta definir la extensión funcional y anatómica de la enfermedad de las células insulares y su relación con la evolución clínica en pacientes con el síndrome NEM I.

Los especímenes de resección pancreática en 14 pacientes con síndrome NEM I fueron examinados para hiperplasia, nesidioblastosis, tumores múl- 
tiples y evidencia de malignidad. Los especímenes representaron el páncreas distal en 12 casos, y la totalidad del páncreas en 2 . Se tomaron secciones múltiples de cada espécimen. La coloración con inmunoperoxidasa fue realizada para gastrina, polipéptido pancreático, glucagón, serotonina, VIP (péptido vasoactivo intestinal), somatostatina $y$ enolasa neuronal específica en secciones de 24 tumores provenientes de 10 pacientes. Cinco de los 10 pacientes con el síndrome de Zollinger-Ellison fueron sometidos a gastrectomía total y otros tres sólo a procedimientos sobre el páncreas orientados al control de su hipersecreción ácida.

Se llega a las siguientes conclusiones: Todos los pacientes con síndrome NEM I y neoplasias pancreáticas poseen afección difusa de las células insulares consistente en nesidioblastosis e hiperplasia micro y macronodular. Algunos tumores producen múltiples hormonas y los pacientes se encuentran en riesgo de desarrollar nuevos tumores, pero la resección de tumores aparentes puede resultar en el control a largo plazo de la endocrinopatía existente. Esto es particularmente cierto en pacientes con insulinoma e hipoglicemia.

Algunos pacientes con gastrinoma también pueden ser considerados para resección de su tumor (es) de células insulares sin gastrectomía concomitante, especialmente cuando el muestreo venoso transhepático demuestra un lugar único de excesiva producción de gastrina. Sin embargo, si el muestreo venoso transhepático demuestra fuentes difusas de hipergastrinemia, un procedimiento de resección pancreática local invariablemente fallará. La pancreatectomía total en pacientes con síndrome NEM I con enfermedad localizada del páncreas es el único procedimiento quirúrgico curativo pero está rara vez indicado.

\section{References}

1. Bonfils, S., Landor, J.H., Mignon, M., Hervoir, P.: Results of surgical management in 92 consecutive patients with Zollinger-Ellison syndrome. Ann. Surg. 194:692, 1981

2. Deveney, C.W., Deveney, K.S., Way, L.W.: The Zollinger-Ellison syndrome-23 years later. Ann. Surg. 188:384, 1978

3. Friesen, S.R., Kimmel, J.R., Tomita, T.: Pancreatic polypeptide as a screening marker for pancreatic polypeptide apudoma in multiple endocrinopathies. Am. J. Surg. 139:61, 1979

4. Friesen, S.R.: Treatment of the Zollinger-Ellison syndrome: A 25-year assessment. Am. J. Surg. $143: 331,1982$

5. Friesen, S.R.: Tumors of the endocrine pancreas. N. Engl. J. Med. 306:1533, 1982

6. Lloyd, R.V., Gikas, P.W., Chandler, W.F.: Prolactin and growth hormone producing pituitary adenoma. An immunohistochemical and ultrastructural study. Am. J. Surg. Pathol. 7:251, 1980

7. Thompson, N.W.: Surgical considerations in the MEN I syndrome. In Endocrine Surgery, I.D.A. Johnston and N.W. Thompson, editors. London, Butterworths, 1983, pp. 144-163

8. Glowniak, J.V., Shapiro, B., Vinik, A.I., Glaser, B., Thompson, N.W., Cho, K.J.: Percutaneous transhepatic venous sampling of gastrin: Value in sporadic and familial islet-cell tumors and G-cell hyperfunction. N. Engl. J. Med. 307:293, 1982

9. Vinik, A.I., Glowniak, J., Glaser, B., et al.: Localization of gastroentero-pancreatic (GEP) tumors. In Endocrine Surgery, I.D.A. Johnston and N.W. Thompson, editors. London, Butterworth, 1983, pp. 76-103

10. Majewski, J.T., Wilson, S.D.: The MEA I syndrome: An all or none phenomenon? Surgery $86: 475$, 1979

11. Deveney, C.W., Deveney, K.E., Stark, D., Moss, A., Stein, S., Way, L.W.: Resection of gastrinomas. Ann. Surg. 198:546, 1983

12. Wood, S.M., Bloom, S.R.: Glucagon and gastrin secretion by a pancreatic tumor and its metastases. J.R. Soc. Med. 75:42, 1982

13. Thompson, N.W.: The surgical treatment of islet cell tumors of the pancreas. In Pancreatic Disease. T.L. Dent, editor. New York, Grune \& Stratton, 1981, pp. $4561-471$

14. Brennan, M.F., Jensen, R.T., Wesley, R.A., Doppman, J.L., McCarthy, D.M.: The role of surgery in patients with Zollinger-Ellison syndrome (ZES) managed medically. Ann. Surg. 196:239, 1982

15. Schein, P.S., DeLellis, R.A., Kahn, C.R., Gorden, P., Kraft, A.R.: Islet cell tumors: Current concepts and management. Ann. Intern. Med. 79:239, 1973

16. Zollinger, R.M., Ellison, E.C., Fabri, P.J., Johnson, J., Sparks, J., Carey, L.C.: Primary peptic ulcerations of the jejunum associated with islet cell tumors: Twenty-five year appraisal. Ann. Surg. $192: 422,1980$

17. Malagelada, J.R., Edis, A.J., Adson, M.A., van Heerden, J.A., Go, V.L.W.: Medical and surgical options in the management of patients with gastrinoma. Gastroenterology 84:1524, 1983

18. Wilson, S.D.: The role of surgery in children with the Zollinger-Ellison syndrome. Surgery 92:682, 1982

19. Cho, K.J., Vinik, A.I., Thompson, N.W., Shields, J.J., Porter, D.J., Brady, T.M., Cadavid, G., Fajans, S.S.: Localization of the source of hyperinsulinism: Percutaneous transhepatic portal and pancreatic vein catheterization with hormone assay. A.J.R. 139:237, 1982

20. Gelston, A.L., DeLisle, M.B., Patel, Y.C.: Multiple endocrine adenomatosis type I. J.A.M.A. 247:665, 1982

21. Creutzfeldt, W.: Endocrine tumors of the pancreas. Clinical, chemical and morphological findings. In The Pancreas, P.J. Fitzgerald and A.B. Morrison, editors. Baltimore, Williams \& Williams, 1980, pp. 208-230

22. Larsson, L.I.: Two distinct types of islet abnormalities associated with endocrine pancreatic tumors. Virchows Arch. (Pathol. Anat.) 376:209, 1977

23. Mukai, K., Greider, M.H., Grotting, J.C., Rosai, J.: Retrospective study of 77 pancreatic endocrine tu- 
mors using the immunoperoxidase method. Am. J. Surg. Pathol. 6:387, 1982

24. Solcia, E., Capella, C., Buffa, R., Frigerio, B., Fiocca, R.: Pathology of the Zollinger-Ellison syndrome. In Progress in Surgical Pathology, vol 1, C.M. Fengolio and M. Wolff, editors. New York, Mason Publishing USA, Inc., 1980, pp. 119-133

25. Woodtli, W., Hedinger, C.: Histologic characteristics of insulinomas and gastrinomas. Virchows Arch. (Pathol. Anat.) 371:331, 1976

26. Hoffman, J.W., Fox, P.S., Wilson, S.D.: Duodenal wall tumors and the Zollinger-Ellison syndrome: Surgical management. Arch. Surg. 107:334, 1973

27. Lasson, A., Alwmark, A., Nobin, A., Sundler, F.: Endocrine tumors of the duodenum: Clinical characteristics and hormone content. Ann. Surg. 197:393, 1983

28. Oberhelman, H.A., Jr.: Excisional therapy for ulcerogenic tumors of the duodenum-long-term results. Arch. Surg. 104:447, 1972

29. Davies, C.J., Joplin, G.F., Welbourn, R.B.: Surgical management of the ectopic ACTH syndrome. Ann. Surg. 196:246, 1982

30. O’Neal, L.W., Kipnis, D.M., Luse, S.A., Lacy, P.E., Jarett, L.: Secretion of various endocrine substances by ACTH-secreting tumors-gastrin, melanotropin, norepinephrine, serotonin, parathormone, vasopressin, glucagon. Cancer 21:1219, 1968

31. Barreras, R.F., Mack, E., Goodfriend, T., Damm, M.: Resection of gastrinoma in the Zollinger-Ellison syndrome. Gastroenterology 82:953, 1982

32. Debas, H.T., Soon-Shiong, P., McKenzie, A.D., Bogoch, A., Greig, J.H., Dunn, W.L., Magill, A.B.: Use of secretin in the roentgenologic and biochemical diagnosis of duodenal gastrinoma. Am. J. Surg. 145:408, 1983

33. Wolfe, M.M., Alexander, R.W., McGuigan, J.E.: Extra pancreatic, extra intestinal gastrinoma. N. Engl. J. Med. 306:1533, 1982

34. Burcharth, F., Stage, J.G., Stadil, F., Jensen, L.I., Fischermann, K.:Localization of gastrinomas by trans- hepatic portal catheterization and gastrin assay. Gastroenterology 77:444, 1979

35. Roche, A., Raisonnier, A., Gillon-Savouret, M.D.: Pancreatic venous sampling and arteriography in localizing insulinoma and gastrinomas: Procedure and results in 55 cases. Radiology 145:621, 1982

36. Malagelada, J.R., Glanzman, S.L., Go, V.L.W.: Laboratory diagnosis of gastrinoma II: A prospective study of gastrin challenge tests. Mayo Clin. Proc. 57:219, 1982

37. Malagelada, J.R., Davis, C.S., O'Fallon, M.W., Go, V.L.W.: Laboratory diagnosis of gastrinoma I. A prospective evaluation of gastric analysis and fasting serum gastrin levels. Mayo Clin. Proc. 59:211, 1982

38. Richardson, C.T., Feldman, M., McClelland, R.N., Dickerman, R.M., Kumpuris, D., Fordtran, J.S.: Effect of vagotomy in Zollinger-Ellison syndrome. Gastroenterology 77:682, 1979

39. Sircus, W.: Vagotomy in ZE syndrome. Gastroenterology 79:607, 1980

40. Charboneau, J.W., James, E.M., van Heerden, J.A., et al.: Intraoperative real-time ultrasonic localization of pancreatic insulinoma-initial experience. J. Ultrasound Med. 2:251, 1983

41. Sigel, B., Coelho, J.C.U., Spigos, D.G., Donahue, P.E., Wood, D.K., Nybus, L.M.: Ultrasonic imaging during biliary and pancreatic surgery. Am. J. Surg. 141:84, 1981

42. Case Records of the Massachusetts General Hospital (Case 1-1983). N. Engl. J. Med. 308:30, 1983

43. Harness, J.K., Geelhoed, G.W., Thompson, N.W., Nishiyama, R.H., Fajans, S.S., Kraft, R.O., Howard, D.R., Clark, K.A.: Nesidioblastosis in adults: A surgical dilemma. Arch. Surg. 1/6:575, 1981

44. Keller, A., Stone, A.M., Valderamma, E., Kolodny, H.: Pancreatic nesidioblastosis in adults. Am. J. Surg. 145:412, 1983

45. Vance, J.E., Stoll, R.W., Kitabachi, A.E., Williams, R.H., Wood, F.C., Jr.: Nesidioblastosis in familial endocrine adenomatosis. J.A.M.A. 207:1679, 1969

\title{
Invited Commentary
}

\author{
Jeffrey A. Norton, M.D.
}

Surgical Metabolism Section, Surgery Branch, National Cancer Institute, National Institutes of Health, Bethesda, Maryland, U.S.A.

This important work by Thompson and associates defines the extent of pancreatic disease in patients with multiple endocrine neoplasia, type I (MEN I). In their careful analysis, Thompson et al. describe diffuse islet cell hyperplasia, microadenomas, ne- sidioblastosis, and gross tumors in nearly all patients. They describe multiple tumors in half of the patients and nodal metastases in $29 \%$. These findings explain observations that endocrine surgeons have made for years; that is, surgery for pancre- 